\title{
Angioectasias on the major and accessory duodenal papillae; a unique cause of recurrent bleed in a patient with von Willebrand's disease
}

\author{
Dimitrios E Sigounas, ${ }^{1}$ Diana E Yung, ${ }^{1}$ John N Plevris, ${ }^{1}{ }^{1,2}$ Anastasios Koulaouzidis ${ }^{1}$
}

${ }^{1}$ Centre of Liver and Digestive Disorders, Royal Infirmary of Edinburgh, Edinburgh, UK ${ }^{2}$ Medical School, The University of Edinburgh, Edinburgh, UK

\section{Correspondence to} Dr Anastasios Koulaouzidis, akoulaouzidis@hotmail.com

Accepted 31 October 2015
CrossMark

To cite: Sigounas $D E$, Yung DE, Plevris JN, et al. BMJ Case Rep Published online: [please include Day Month Year] doi:10.1136/ bcr-2015-210781

\section{DESCRIPTION}

An 83-year-old woman with von Willebrand's disease $(\mathrm{vWD})$ presented with multiple episodes of gastrointestinal bleeding over the past few years, leading to symptomatic anaemia. She underwent bidirectional negative endoscopies and MR cholangiopancreatography (MRCP). Small bowel capsule endoscopy (SBCE) revealed intraluminal blood clots and a $\mathrm{P}^{1}$ lesion on the ampulla of Vater (AoV) (figure 1A, B). Further upper digestive endoscopy with a side-viewing endoscope identified active bleeding from both the major and accessory papillae (figure 2A-D). Argon plasma coagulation (APC) was applied for haemostasis. Repeat SBCE documented active bleeding from the previously seen P0 lesion on the AoV (figure 3). Repeat APC on both papillae was performed with improvement of anaemia, although it was still ongoing. The patient remained asymptomatic thereafter.

Bleeding from the AoV is a rare SBCE finding. However, an association between $\mathrm{vWD}$ and small bowel angioectasias has been suggested; in an international survey regarding the complications of $\mathrm{vWD}$, the prevalence of angiodysplasias in
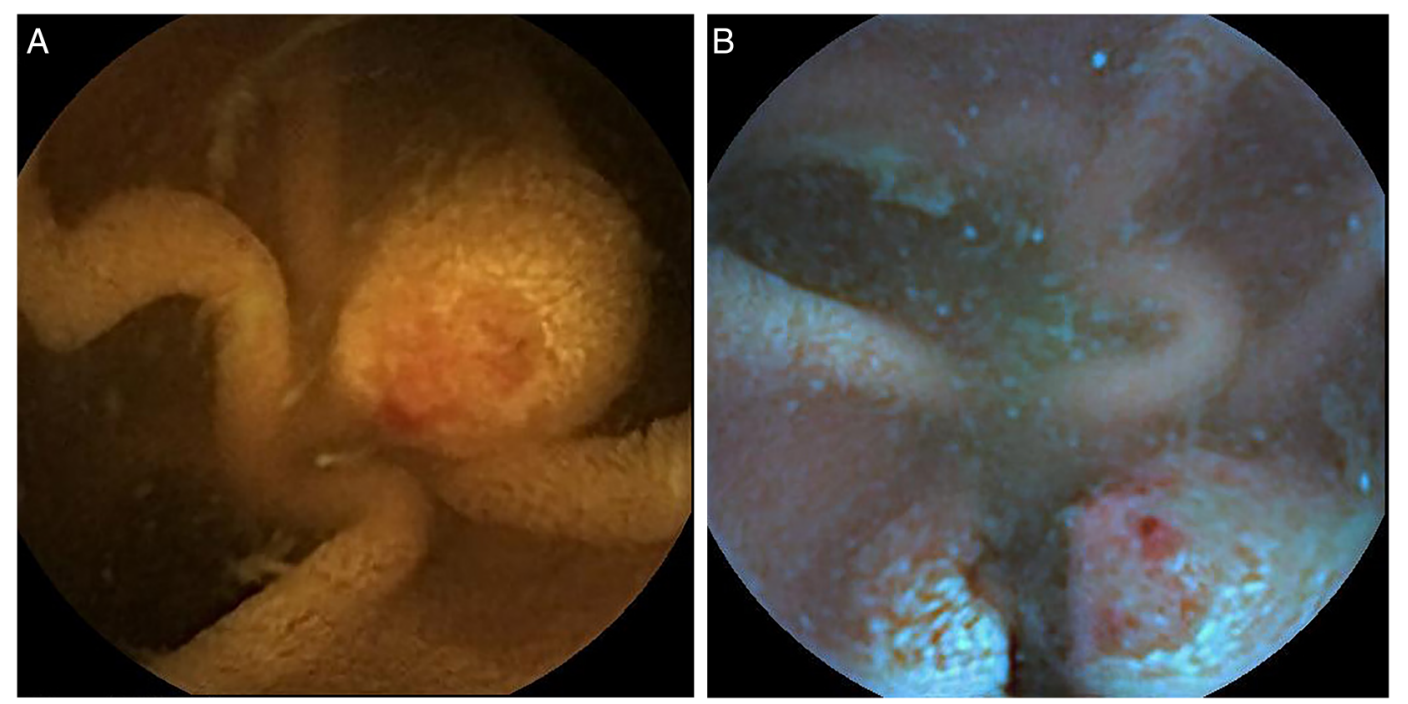

Figure 1 ( $A$ and B) PO lesion at the ampulla of Vater (AoV), first seen on initial small bowel capsule endoscopy. type $2 \mathrm{vWD}$ was $2 \% .^{2}$ This is a rare report of bleeding angiodysplasias on the major and accessory papillae in a patient with $\mathrm{vWD}$. This 'rarity' might be due to difficulty assessing the papilla using forward-viewing gastroscopes as well as the inherent inability of SBCE to visualise the AoV in the majority of cases. ${ }^{3}$ It is difficult to explain why such lesions were located on the major and accessory papillae. In the context of $\mathrm{vWD}$, depletion of $\mathrm{vWD}$ factor from terminal vessels in the sphincter areas where shear flow is high is a plausible explanation.

\section{Learning points}

- Red spots are usually characterised as P0 and considered of little clinical significance.

- However, such lesions may become more significant in the context of a patient with bleeding diathesis: in our case, it was the cause of recurrent anaemia. 

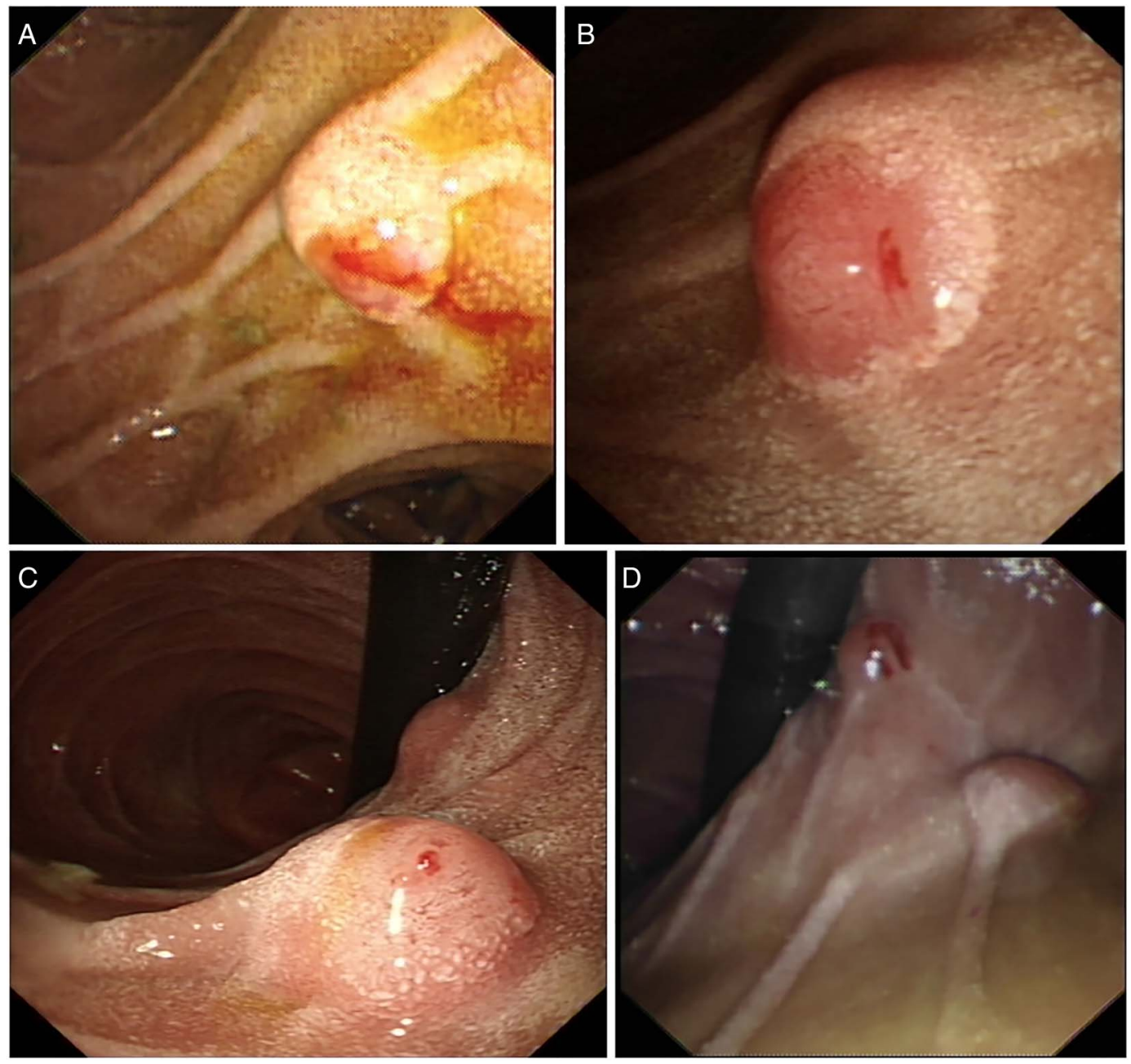

Figure 2 (A-D) Active bleeding from both major and accessory papillae, as seen via side-viewing endoscope.

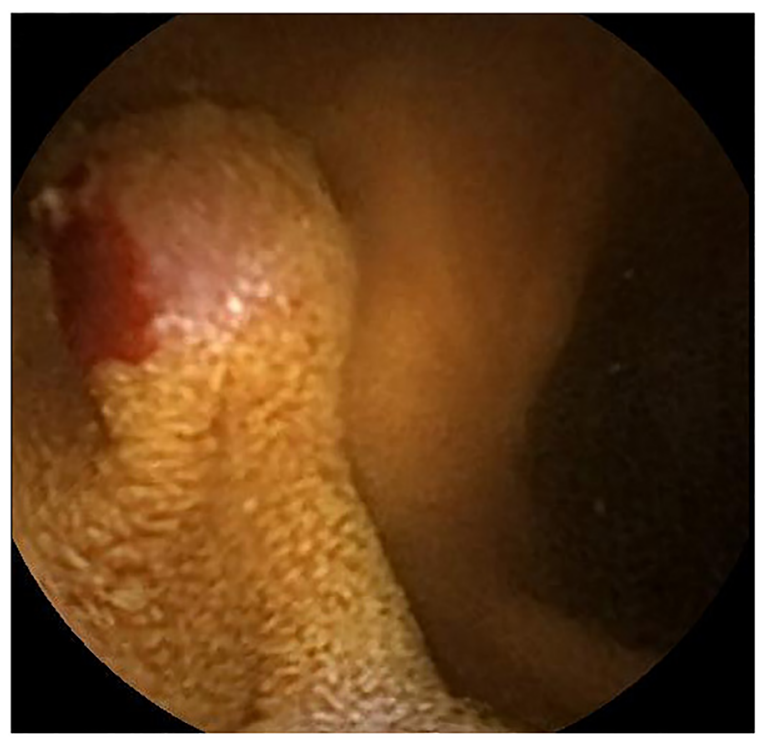

Contributors DES and AK collected the images and wrote up the case. DEY performed further editing and prepared the case for submission. JNP supervised the process as a whole.

Competing interests None declared.

Patient consent Obtained.

Provenance and peer review Not commissioned; externally peer reviewed.

\section{REFERENCES}

1 Saurin JC, Delvaux M, Gaudin JL, et al. Diagnostic value of endoscopic capsule in patients with obscure digestive bleeding: blinded comparison with video push-enteroscopy. Endoscopy 2003;35:576-84.

2 Fressinaud E, Meyer D. International survey of patients with von Willebrand disease and angiodysplasia. Thromb Haemost 1993;70:546.

3 Koulaouzidis A, Plevris JN. Detection of the ampulla of Vater in small bowel capsule endoscopy: experience with two different systems. J Dig Dis 2012;13:621-7.

Figure 3 Active bleeding from the same lesion as in figure 1, documented on repeat small bowel capsule endoscopy. 
Copyright 2015 BMJ Publishing Group. All rights reserved. For permission to reuse any of this content visit http://group.bmj.com/group/rights-licensing/permissions.

BMJ Case Report Fellows may re-use this article for personal use and teaching without any further permission.

Become a Fellow of BMJ Case Reports today and you can:

- Submit as many cases as you like

- Enjoy fast sympathetic peer review and rapid publication of accepted articles

- Access all the published articles

- Re-use any of the published material for personal use and teaching without further permission

For information on Institutional Fellowships contact consortiasales@bmjgroup.com

Visit casereports.bmj.com for more articles like this and to become a Fellow 